\title{
Quality Assurance for Postgraduate Programs: Design of a Model Applied on a University in Chile
}



Marcelo Careaga Butter', Eduardo Meyer Aguilera², María Graciela Badilla Quintana', Laura Jiménez Pérez ${ }^{1}$, and Eileen Sepúlveda Valenzuela ${ }^{1}$

1 Universidad Católica de la Santísima Concepción, ${ }^{2}$ Pontificia Universidad Católica de Valparaíso

\begin{abstract}
The quality of Education in Chile is a controversial topic that has been in the public debate in the last several years. To ensure quality in graduate programs, accreditation is compulsory. The current article presents a model to improve the process of self-regulation. The main objective was to design a Model of Quality Assurance for Postgraduate Programs in order to constitute a theoretical, mathematical, and informatics reference that would optimize the processes of self-regulation, selfevaluation, and accreditation of master and doctorate programs from the Universidad Católica de la Santísima Concepción, Chile. This descriptive research is based on a mixed methods approach. The proposal was intended through theoretical and empirical references related to the accreditation systems. The analysis process was conducted with key informants, and the informatics instrument was created and validated through expert judgment. After the analysis, the model was optimized considering the expert's suggestions. As a result of the optimization process, a matrix of eight dimensions was obtained and it is available online in order to be used by the heads of postgraduate programs. Finally, a model with four main stages was achieved in order to install a self-regulation and a self-evaluated culture that leads to accreditation as evidence of the quality of postgraduate programs.
\end{abstract}

Keywords: quality of education, digital technologies, online platform, benchmark of quality, postgraduate programs 
Quality Assurance for Postgraduate Programs: Design of a Model Applied on a University in Chile

Careaga Butter, Meyer Aguilera, Badilla Quintana, Jiménez Pérez, and Sepúlveda Valenzuela

\section{Quality Assurance for Postgraduate Programs: Design of a Model Applied on a University in Chile}

Discussion of quality benchmarks in postgraduate programs has become highly relevant. Examples of this process across the world include the following: Universities in USA are accredited by national agencies such as Accreditation Board for Engineering and Technology (ABET), National Architectural Accreditation Board (NAAB), Liaison Committee on Medical Education (LCME) and American Bar Association (ABA). In Latin America, countries like Brazil and Argentina present experience in the accreditation of postgraduate programs, in charge of the Coordenação de Aperfeiçoamento de Pessoal de Nivel Superior (CAPES) and Sistema Interuniversitario de Cuarto Nivel (SICUN). In Spain, ANECA through the Program Mención gives the excellence and recognition of the country's universities. Chile has experience with the National Accreditation Commission, in charge of the institutional accreditation of undergraduate and postgraduate programs (Comision Nacional de Acreditación, 2013).

In general terms, starting an accreditation process involves completing a self-evaluation report. The institutions must have a permanent self-regulation process that shows the weaknesses and strengths of the programs' implementation. However, it is convenient to have an established plan to regulate their practice. This article addresses the importance of supporting these actions. One example is the Postgraduate Direction from the Universidad Católica de la Santísima Concepción (UCSC), which has developed a model based on theoretical national and international framework to guide the selfregulation, self-evaluation, and accreditation processes.

The proposed idea was born from the emerging problem in the Chilean Educational system. This is related to the excellent training of people in the different areas of knowledge which are contextualized in the new cultural settings.

\section{Theoretical Framework}

\section{The Concept of Quality in Education}

Quality is considered by the International Organization for Standardization (ISO) in its norm ISO 9000: 2000 as the degree in which essential features achieve requirements (Colin, 2002). This definition is complemented by Juran \& Godfrey (2001), for whom there are two vital definitions of quality. First, it means that those product's characteristics meet customer needs and satisfy them (related to income). Second, quality means no deficiencies or absence of errors requiring rework or resulting in faulty operation, customer dissatisfaction and/or complaints (oriented to costs). These concepts are closely linked to the concept of total quality or excellence or total quality management that have been defined as any kind of forms through which the institution meets the needs and expectations of its clients, its workers, entities involved financially, and society in general (Santillán \& Asmat, 2015). 
Quality Assurance for Postgraduate Programs: Design of a Model Applied on a University in Chile

Careaga Butter, Meyer Aguilera, Badilla Quintana, Jiménez Pérez, and Sepúlveda Valenzuela

The quality of the Chilean education is being treated as a demand that emerges from the social, political, and economic system to the educational system. It has been focused on learning achievements, results on standardized tests, teachers' performance, and comparison with standards emanating from the international context. This situation is contextualized on the demands that emerge from the incorporation of Chile to the countries of the Organization for Economic Cooperation and Development (OECD, 2013).

The quality of education enables us to understand it located in structural complexities, cultural connotations, and the epistemological, social, and ethical implications. It is intimately linked with the academic excellence that can be understood as the quality of ideas, ethical principles and superior actions (beyond the minimum required).

Pedagogically, the quality of learning should be measured not only by the ability to manage information, the intellectual and cognitive ability to evoke theoretical concepts, and practical experiences recorded in memory, because it might primarily place emphasis on the ability to coconstruct knowledge. At the same time, it is vital to consider the current cultural transition towards a fully globalized society, in which students learn in virtual and face-to-face contexts. The skills and knowledge might be assessed as intellectual, theoretical, and practical constructs mid by any kind of language. The quality of learning should be formalized, as metacognitive and meta-language through a communicational ability of students. To assess quality of learning, it is useful to diagnose knowledge, competences, skills, and ethical values from the students' repertoire of previous experiences. To educate on quality and based on academic excellence is look at more than standardized test weights. It is an explicit distinction between educating for progress, which is economic and material development, and educating for development, which is to integrate the human and cultural aspects.

The quality of education is emerging potentially and auspiciously in people who are responsible for a fair and equitable society, a distributive and sustainable economy, and a vibrant culture.

\section{Referents to Create the Model}

Chilean literature review. The Interuniversity Development Center, an international non-profit corporation created to promote linkages between leading universities in Latin America and Europe, defines quality assurance as a common name for a variety of mechanisms to monitor, ensure, and promote the quality of higher education institutions, which contributes to a better understanding of these processes as an aspect of progressive development (Centro Interuniversitario de Desarrollo, 2012).

In 2006, the law 20.129 established a National System of Quality Assurance in Higher Education and defines the Comision Nacional de Acreditación (CNA, National Accreditation Commission) and the advisory committees' quality assessment. This system is materialized through the implementation of 
Quality Assurance for Postgraduate Programs: Design of a Model Applied on a University in Chile

Careaga Butter, Meyer Aguilera, Badilla Quintana, Jiménez Pérez, and Sepúlveda Valenzuela

four functions: information, licensing of new institutions, institutional accreditation, and accreditation of programs (Pitta, 2013). CNA and advisory committees define the criteria and procedures applicable to the accreditation of programs and institutions. The system of quality assurance at universities is based on a process of continuous improvement, which can be seen as a cyclical process of self-regulation, where the self-evaluation and comparison with standards is a fundamental component to design and implement improvement measures required. This selfevaluation is contrasted with the observation and expert judgment of external peers.

In the case of postgraduate programs, self-evaluation is understood as a process in which the active community of a particular program (administrators, academics, students and graduates, as well as representatives of labour and business sector) critically examines the operation of the program, in order to detect their strengths and weaknesses and ensure quality. In this sense, the self-evaluation process requires the active participation of all the actors involved in the program and they are fully aware of the scope and objectives of the process in which they are involved.

Regarding the comparison standards, CNA provides only criteria, which define some general requirements in the following areas:

- character and program objectives,

- admission requirements,

- programme length,

- programme structure,

- thesis procedures (doctoral or master),

- $\quad$ rating and qualification of teachers of the program, and

- institutional support for the program.

The evaluation instruments considered in the process of accreditation of the programs are:

- a self-evaluation report,

- a background report, and

- $\quad$ an external evaluation report.

The critical point of this process is that since there are no indicators and globally accepted standards, self-evaluation is based on the standards and indicators that the institution sets. External evaluators, however, have their own mental models about what the desired values are. This can cause major 
Quality Assurance for Postgraduate Programs: Design of a Model Applied on a University in Chile

Careaga Butter, Meyer Aguilera, Badilla Quintana, Jiménez Pérez, and Sepúlveda Valenzuela

difficulties in this process. For this reason, it is highly desirable that the institution establishes standards and generally accepted nationally and internationally indicators.

International literature review. United Nations Educational, Scientific and Cultural Organization (UNESCO, 2009) states that quality standards must reflect all the objectives of higher education: especially, to foster in students critical and independent thinking and ability to learn throughout life. Moreover, the Accreditation Manual sets clear expectations in the areas of academic quality, educational services, continuous improvement, and ethical financial practices (Distance Education Accrediting Commission [DEAC], 2016).

In 2003, the ministers of the signatory states of the Bologna Process invited the European Network for Quality Assurance in Higher Education (ENQA, 2009) to develop an agreed set of standards, procedures, and guidelines for quality assurance. Also they wanted to explore ways to ensure an adequate peer review system for quality assurance or agencies or accreditation bodies (or a system and agency or accreditation body). These criteria and general guidelines cover all higher education and have no special requirements on the postgraduate. European accreditation programs exist in some areas of postgraduate study (e.g., MBA) by specialized agencies.

The quality code in the United Kingdom is the definitive reference for all providers of higher education at all levels. In this code, or listing standards, the Quality Assurance Agency sets out what the public expects of them. This code was lifted from the expectations of all relevant actors, students, teachers, parents, employers, and industry. It covers the four nations of the UK and all institutions of higher education that operate internally or abroad. It was developed primarily to protect the interests of students, regardless of whether they are full or part time, or undergraduate or postgraduate. Only B11 chapter of this code specifically refers to postgraduate programs and establishes 18 specific indicators for these programs (QAA, n.d.). The other indicators in the rest of the code refer to all programs at both the undergraduate and postgraduate levels.

In the United States (US) there are so many local, state, and federal agencies that accredit universities or careers (more than 60). There is no single system, however, is in the country's culture, widely settled the notion of assessment, which translates as though assessment goes beyond that. The institutions must be held accountable by the public or private funds spent and the quality of the products or services delivered to consumers. There is Commissions Regional Council Accreditation (C-RAC), formed as a professional association dedicated to improve education through accreditation (El-Khawas, 2007).

Another feature of the accreditation process in the US is the initiatives arising from the same institutions. Accreditation was defined as the process of self-regulation and external peer review adopted by the entire educational community. There is no major conceptual difference between the assessment of undergraduate and postgraduate level programs, and the emphasis is kept on teaching (Middle States Commission on Higher Education, 2009). 
Quality Assurance for Postgraduate Programs: Design of a Model Applied on a University in Chile

Careaga Butter, Meyer Aguilera, Badilla Quintana, Jiménez Pérez, and Sepúlveda Valenzuela

One of the experiences applied in the Anglo-Saxon context was called Modelling Criteria for Measuring and Evaluating the Quality of Education of the University. The document was based on the premise that the quality of university education has to be measured by quantitative assessments establishing preliminarily defined criteria, depending on the individual indices on the quality of training (Hristova \& Zhelezarov, 2006).

The functions of multi-componential indexes, the correlation dependencies between them, and the criteria weight coefficients have been studied applying the method of evaluation experts. It suggest that the quality of training can be controlled and evaluated according to three different approaches:

- At the exit, where knowledge, skills, dispositions, and values acquired by students at the time of formation (absolute quality assessment) are verified.

- Added value method, in which the difference between the input and output level is requested. This difference is classified on the effectiveness in the process of training and quality of the education product.

- About quality has indirectly in separate parts, elements, and processes, conditions and requirements by passing the educational process.

The assumption of this approach is that if all these answers at most quality requirements then the quality will possess a high valuation.

The measurement of the quality of university education and receiving quantitative estimates of its evaluation is one of the conditions necessary for success management and quality improvement as a whole.

Assessment and quality certification of Higher Distance Education. It is clear that any methodology for learning should prove useful and positive, and in this sense there are already many global initiatives that work for the establishment of standards to certify the quality of e-learning projects (Sangrà, 2001b; Rubio, 2003).

In Chile, the wide range in Higher Distance Education (DHE) contrasts with the absence of specific regulations and incentives that encourage the development of a range of quality education. While the current National System of Quality Assurance of Higher Education establishes generic standards not expressly exclude the Higher Distance Education manner, this legislation omits identify and establish criteria specifically adapted to the characteristics of an educational model structured on the basis of self-learning mediated by technology requirements, flexibility and globalization.

In this sense it can say that the existing institutions in the field of quality assurance does not provide real quality guarantees regarding distance higher education. This situation not only remains valid comparative academic results obtained product of this type of education in relation to the traditional classroom model, but it is a potential risk to people who choose to be formed through this modality. 
Quality Assurance for Postgraduate Programs: Design of a Model Applied on a University in Chile

Careaga Butter, Meyer Aguilera, Badilla Quintana, Jiménez Pérez, and Sepúlveda Valenzuela

The reality presented in Chile in the area of quality assurance of Higher Distance Education contrasts with the significant experiences in the international arena regarding the evaluation and certification of the quality of this educational modality. Some initiatives provide an overview and recommendations, for example: the study about Quality On the Line, Benchmarks for Success in Internet-based Distance Education (The Institute for Higher Education Policy, 2000), and Guidelines for the Evaluation of Electronically Offered Degree and Certificate Programs (The Council of Regional Accrediting Commissions, 2009). Quality models in online and open education around the globe include State of the art and recommendations, from the International Council for Open and Distance Education (Ossiannilsson, Williams, Camilleri, \& Brown, 2015) and Benchmarking of Virtual Campuses, BENVIC Project (Sangrà, 2001a), among others.

Also useful are evaluation and certification models of the quality of Higher Distance Education developed by: a) National Accreditation System of Higher Education (SINAES) of Costa Rica; b) Distance Education Accrediting Commission (DEAC), United States; and c) Latin American and Caribbean Institute for Quality in Higher Distance (CALED) for Latin America and the Caribbean Education, through its Project "Virtual Centre for the Development of Quality Standards for Higher Distance Education in Latin America and the Caribbean " (CALED, n.d.).

The CALED model presents a structure consisting of: criteria, sub-criteria, objectives, standards, and indicators. In its basic definitions, it declares a quality concept, objectives, management model, and an evaluation model, strongly associated with efficiency and effectiveness and whose antecedent is the Ibero-American Model of Excellence in Management (Rubio, Aguilar, Massa, Maldonado, and Ramírez, 2005). It also establishes a standard definition that promotes continuous improvement and has been valued and incorporated by other models in Latin America.

The Accreditation Manual DEAC established 12 areas of interest in detailing policies, practices, and standards that allow for the appropriate comparison and determine the distance between reality and standard. Some of these are: Mission, Purpose, and Objectives; Educational Objectives, Curriculum and Materials Program; Educational Services; Student Support Services; Satisfaction and Student Achievement; Owners, Managers, Heads of Faculty, Administration Committed, reputation of the institution; Practices Admission and Registration contracts; Advertising, promotional literature, and recruitment of personnel; Financial responsibility; Requirements for Discounts, Returns, and Cancellations; Facilities, Equipment, and Supplies; and finally Research and Auto-Improving (DEAC, 2015).

SINAES model aims to evaluate the program based on four dimensions: Relationship Context, Means, Educational process, and Results. This evaluation model seeks to visualize, in an inclusive manner, the main elements of the educational process. This is an environment that contextualizes resources or inputs needed for the educational process, the process itself, and results. These elements are called dimensions and are evaluated taking into consideration the characteristics of each program. Additionally, the model identifies four elements that complement the evaluation: Eligibility criteria, 
Quality Assurance for Postgraduate Programs: Design of a Model Applied on a University in Chile

Careaga Butter, Meyer Aguilera, Badilla Quintana, Jiménez Pérez, and Sepúlveda Valenzuela

Sustainability criteria of accreditation and improvement of the program, Meta-evaluation, and Reaccreditation (SINAES, 2011).

In this context, the problem that arises through the literature review, and in Chile specifically, is that there are no reference models that provide dimensions, categories, standards, and indicators to ensure the quality of postgraduate programs. Therefore, in the following sections it is going to present the general guidelines about the university context where the idea about a Model of Quality Assurance for Postgraduate Program was conceived. This model will provide the first step to have a theoretical framework, mathematician and computer application, as instrumental to evaluate these programs.

\section{General Guidelines about the University Context}

The Universidad Católica de la Santísima Concepción (UCSC) is located in the Bío Bío Region and it is part of the Rectors Council which is an organization that coordinates the academic work of the nation, the 25 public and traditional universities are leaders in research and have institutional accreditation (Consejo de Rectores de las Universidades Chilenas, N/D).

The UCSC has 9000 undergraduate students in 52 majors, and 512 Postgraduate students in 22 master and two doctoral programs.

The context that determines the vision and the Declaration of the Principles of UCSC, in relation to the development of knowledge and contribution to society, can highlight that it is a Catholic institution and it has always been recognized as an incomparable creativity and dissemination centre of knowledge for the good of humanity.

The mission of the university is "to promote, from the Bío Bío Region, the generation and application of knowledge, contributing to the cultural, economic, scientific, moral, spiritual, and social development of the country, supported by a comprehensive educational project, of a high quality standard" (UCSC, 2012).

The guiding principles for the formulation of the Model of Quality Assurance for Postgraduate Programs (MQAPP) have been obtained from formal document of the university such as: the Strategic Development Plan 2012/2016 (UCSC, 2012), the Educational Project of the Institution (UCSC, 2003), and the University Curriculum Framework (UCSC, 2010).

The strategic lines of this plan as they relate to the development of postgraduate programs considered for the model are (UCSC, 2012): the university as a leading knowledge generation and training of people at the highest academic level centre, and the university as an outstanding service centre in the region and major player in the development of the society. 
Quality Assurance for Postgraduate Programs: Design of a Model Applied on a University in Chile

Careaga Butter, Meyer Aguilera, Badilla Quintana, Jiménez Pérez, and Sepúlveda Valenzuela

Regarding the educational project, the institution emphasizes the need to collect the formation demands of high-level specialists who must be able to research and make innovation projects related to knowledge generation, scientific, technological, social, and cultural development. Moreover, the university considers that postgraduate "is the proper and adequate environment for the development of research to the level required by its mission" (UCSC, 2003, p. 4).

The University Framework defines the curricular guidelines to create new programs and update the old ones. It adopts the learning outcomes and competences model (García Retana, 2011) because it is pertinent with its component of responsibility and its capacity of integrating the knowledge.

In this context, the main objective of this research is to describe the design of a model of quality assurance for postgraduate programs.

\section{Methodology}

This research is developed under a pragmatic philosophical paradigm and based on a mixed methods approach (Johnson, Onwuegbuzie, \& Turner, 2007). Mixed methods represents a set of systematic and empirical research and critical processes. It involves the collection and analysis of qualitative and quantitative data, as well as their integration and joint discussion, to make inferences from all the information gathered and greater understand the phenomena studied. Indeed, a quantitative research is oriented towards the description, prediction, and explanation. It is directed towards the measurable or observable data. Furthermore, the qualitative research is oriented to the exploration, the description, and the understanding of the phenomena (Hernández Sampieri, Fernández Collado, $\&$ Baptista Lucio, 2010). Moreover, it is a cross-sectional research because the information is obtained in a unique moment in time.

The main aim was to design a model of quality assurance for postgraduate programs, by describing a theoretical, mathematical, and informatics benchmarks in order to optimize the processes of selfregulation, self-evaluation, and accreditation of postgraduate programs from Universidad Católica de la Santísima Concepción (UCSC) in the Bío Bío Region.

First, a questionnaire was used to gather information. To complete it, the national and international state of knowledge and art was considered through academic databases and institutional documentation. Second, the informatics instrument considered a matrix with eight dimensions, 48 categories, 126 standards and 152 indicators for validation. They were made from the theoretical design. Third, the validation process was conducted through expert judgment (national and international) and users. The specialities of this experts were: informatics specialist, psychologist, engineer, teachers, postgraduate and research directors, and vice rectors. Heads from 18 UCSC postgraduate programs participated as users and 13 as judges. Programs involved in this process were: Doctorate in Education, Master of Science in Education (accredited), Master in Higher Education (accredited), Master in Psychology, Master in Mathematics Education, Master in Applied 
Quality Assurance for Postgraduate Programs: Design of a Model Applied on a University in Chile

Careaga Butter, Meyer Aguilera, Badilla Quintana, Jiménez Pérez, and Sepúlveda Valenzuela

Linguistics, Master in Computer Education and Knowledge Management, Master in Food Management, Master in Geotechnical Engineering, Master of Industrial Engineering, Master in Marine Ecology, Master of Science in Family Counseling and Family Mediation, Master in Family and Community Health, Master in Private Law, Master in Family Law Procedure, Master in Tax and Financial Management, Master in Business, and Master in Creative Communication.

For analysis of the validation process the Delphi method was used, which seeks the consensus of a group of experts based on the analysis and reflection of a defined problem (Varela-Ruiz, Díaz-Bravo, \& García-Durán, 2012).

The three implemented phases of the Delphi method to validate the model were:

- Preliminary phase: the basic elements of the model were established through theoretical analysis and literature review.

- Exploratory phase: an analysis of the matrix validation of expert judgment and users was made in order to receive feedback from the users and judges. The validation procedure consisted of sending a questionnaire to each coordinator to be digitally self-completed. The deadline was three weeks for return by e-mail. The data were transferred to an Excel spreadsheet for further analysis using descriptive statistics procedures, including analysis of mean, standard deviation, minimum, and maximum. The matrix described was sent with a letter of invitation and instructions to complete it. Then, a semantic differential scale, with values ranging between 1 and 5, was used to evaluate each category and their respective indicators, where the opposite adjectives are Rejected (which is equal to the lower acceptance level of the claim) and Accepted (which is equal to the highest acceptance level of claim 5).

- Final phase: The implementation of the model on a computing platform with information obtained from the previous analysis.

\section{Results: A Model of Quality Assurance for Postgraduate Programs}

Main result of this research is related to the development of a model constituted by three elements: the references frames, the theoretical and mathematical; and an informatics platform, on which is implemented. Furthermore, the validation of expert and user judgment's result are shown.

\section{The Theoretical Frame}

This study was a deep analysis of the theoretical and empirical frameworks related to quality assurance in Chile and other countries. It was formed by dimensions, categories, standards, and indicators. 
Quality Assurance for Postgraduate Programs: Design of a Model Applied on a University in Chile

Careaga Butter, Meyer Aguilera, Badilla Quintana, Jiménez Pérez, and Sepúlveda Valenzuela

The dimensions are the macro-references that allow structuring the rationality of the model as a coherent conceptual base that is able to define the internal and external requirements of the university. The dimensions set levels of complexity and derive the same categories as sub-groups and the standards and indicators to assess and measure achievements. The dimensions indicate the direction of the actions and cover the hallmarks of the whole, as an integrated piece. They are defined by the need to bring together the object of knowledge in a single articulated conceptual base. The dimensions considered in the model are: Institutional, Curricular, Academic, Research, Management, Infrastructure, Services, and Institutional Relationships.

The categories are hierarchy grades within a particular order. They constitute a second level of conceptual deductive grouping that brings coherence to the model in order to identify sub-groups within the dimensions. A category can form a philosophical concept, and if it is mixed with other referents, allows a first classification of some very large groups, considering all actual or mental beings in certain taxonomy or classification of objects, things, or ideas.

A standard is a generally accepted norm. It can be facts, resulting from a spontaneous process or following a formal acceptance. In this case, it is a set of rules that specify the design and implementation features that should have a Model of Quality Assurance, with the specific hallmark of the UCSC. In the model the standards are detailed, which have been grouped according to the dimensions and categories containing them, for the purpose of specifying through qualitative and quantitative indicators that can be observed or measured (or both).

Finally, an indicator is a qualitative or quantitative benchmark that allows evaluating by observation or measurement: the realization of a standard. It is a measure that allows warning parameters of progress in achieving objectives and targets that provide a simple and reliable means to measure achievement, reflect changes connected to an intervention, or to help assess the results of a development agency.

The validation technique is based on a semantic differential scale developed by the experts, and refers to establishing the relationship between the standards and categories, setting its relevance, modifying it, or discarding it. Eventually, if experts believe that the standard is adequate, they could assign the maximum score; otherwise, if they consider that it is inadequate, the standard could receive the lowest score.

Thus, through the validation process, the standards are ratified as elements of the model, are eliminated, or are improved, thanks to the flexible design of the model that allows it to incorporate new quality standards.

\section{Mathematical Frame}

The mathematical model is described by a mathematical expression that relates all proposed indicators and calculates a value that represents the percentage of compliance with each dimension. This percentage is a measure of the quality established by institutional criteria (in this case, the 
Quality Assurance for Postgraduate Programs: Design of a Model Applied on a University in Chile

Careaga Butter, Meyer Aguilera, Badilla Quintana, Jiménez Pérez, and Sepúlveda Valenzuela

Universidad Católica de la Santísima Concepción) and external criteria (in this case, the National Accreditation Commission in Chile).

For each standard corresponding to a category of a dimension, four types of indicators were defined: (a) qualitative type, Boolean, (b) qualitative type with 3-5 Likert scale levels, (c) quantitative percentage type, and (d) absolute quantitative type.

Boolean indicators (T/F; 1/O) were used for those standards with exist/not exist quality. For example, if there is a Mission defined, it can be true or false, either 1 or $\mathrm{o}$ in the encoding.

Qualitative indicators with Likert items are used when there is an indicator that can have different levels and it value is obtained through a standard instrument as a survey. For example, the satisfaction level of students for logistics services.

The quantitative percentage indicators are defined on the basis of a maximum value defined on the same indicator. For example, the percentage budget execution according to the plan, it is clear that the percentage is calculated on the total planned budget.

Finally, the absolute quantitative indicators are numbers indicating units or ratios. For example, accrediting years obtained or number of publications per senior teacher.

For each indicator, the expected value is set. This value is estimated considering the evolution in recent years (two to five years), improvement plans, or goals set by the accreditation process.

In order to combine these indicators, they are selected so that the maximum value of the scale, 1 for Boolean, 3, 4 or 5 for the qualitative Likert and, 100\% for the quantitative percentage, correspond to the ideal scenario. Thereafter all indicators are normalized to a decimal value in the range $o$ to 1 , with 1 being the most favourable and o the worst case.

In the special case of absolute quantitative indicators, there is no ideal value, only an expected value; and the highest value does not always correspond to the best result. For example, the indicator average number of students per computer. The expected value is 3 and the maximum acceptable value is 10 students per computer. The normalization was performed by a linear translation, so that 3 corresponds to 1 and 10 corresponds to 0 .

The formula to normalize scales where there is a minimum or maximum value and an expected value is:

$$
I=\frac{x-\text { Maximum or minimum value }}{\text { Expected value }- \text { Maximum or minimum value }}
$$

Where $x$ is the current value and it is within the following range: 


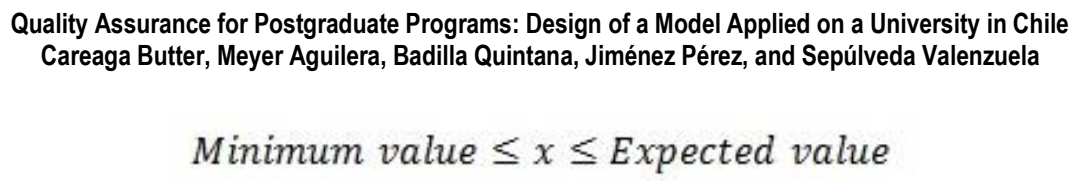

In the case that there is a maximum value:

$$
\text { Expected value } \leq x \leq \text { Maximum value }
$$

These indicators are combined for each of the eight dimensions: Institutional, Curricular, Academic, Research, Management, Infrastructure, Services, and Institutional relationships:

$$
P_{i}=\left[\frac{\sum_{j=1}^{n_{i}} w_{j} I_{j}}{n_{i}}\right] \prod_{k=1}^{n_{C}} I_{k} \times 100
$$

Where:

$$
\begin{aligned}
& i=\text { dimension }, i=1,2,3,4,5,6,7 \text { y } 8 \\
& P_{i}=\text { Score obtained in dimension } i, \text { expresed as a percentage } \\
& n_{i}=\text { Number of indicators of the } i \text { dimension } \\
& w_{j}=\text { Weight of the } j \text { indicator of the } i \text { dimension. } \sum w_{j}=1 \\
& I_{j}=\text { Indicator } j ; 0 \leq I_{j} \leq 1 \\
& I_{k}=\text { Compulsory indicators. Boolean }\left(\begin{array}{ll}
0 & \circ \\
n_{C}
\end{array}\right) . \\
& n_{C}=\text { amount of critical indicators }
\end{aligned}
$$

The compulsory indicators correspond to the minimum required by the national accreditation, and established on the guidelines for the accreditation of graduate programs agency (CNA, 2015), thus mandatory by the university itself through its educational project or strategic plan. These indicators are Boolean: they exist or not. Equation 1 is automatically o for any compulsory $\left(\mathrm{I}_{\mathrm{k}}\right)$ indicator having a zero value. For those compulsory indicators, either because the CNA or UCSC require them, all of them must have the value of one, otherwise the score of the dimension would be zero.

The weights of each indicator in the first prototype are all 1 . The weights can be chosen by an appropriate methodology and the priorities of each graduate program (Middle States Commission on Higher Education, 2009).

The model is designed in a flexible way, so in the future it can assign weights to the different indicators according to the relevance of each and if those required are not present, the quality value is zero.

\section{Informatics Implementation}

In order to design and implement the informatics platform an Incremental Prototype Model was applied. "It is an engineering methodology which is presented as appropriate to collect progressive contributions of users and experts of technological solutions that are designed to meet educational 
challenges" (Careaga Butter, Badilla Quintana, \& Sepulveda Valenzuela, 2014, p.1). It has six phases that are recursive, linking prototypes with pilot programs and stages of expansion and routinization (see figure 1).

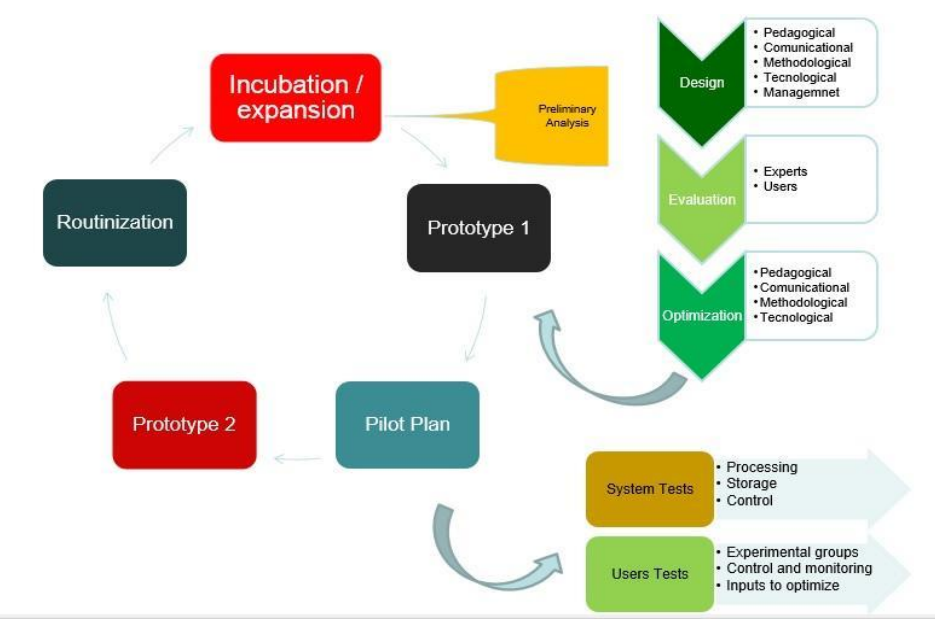

Figure 1. Incremental model prototype (Careaga Butter, Badilla Quintana, \& Sepúlveda Valenzuela, 2014).

The platform is in the prototype stage one; incorporating all dimensions, categories, standards, and indicators; delivering specific results by category and expressed as a percentage of overall quality assurance. The next stage is the development of prototype 2, which will provide a qualitative and quantitative analysis to identify critical indicators.

This platform was designed using PHP and MySQL (free software). It has an account for each master and doctoral program that their coordinators can access using their institutional mail and their passwords. After, they have to complete the information required.

The platform design considered different options of answers that are categorized by scales such as: binary (0-1), range (1-3), numeric (o-N) and percentage (0-100\%). The platform also considers two items to answer: the expected value and actual value. The first one refers to the expected result of each indicator per program and the second one is the actual result at the time of applying the instrument. Individual and total results per dimension are given automatically by the platform (see figure 2). 
Quality Assurance for Postgraduate Programs: Design of a Model Applied on a University in Chile

Careaga Butter, Meyer Aguilera, Badilla Quintana, Jiménez Pérez, and Sepúlveda Valenzuela

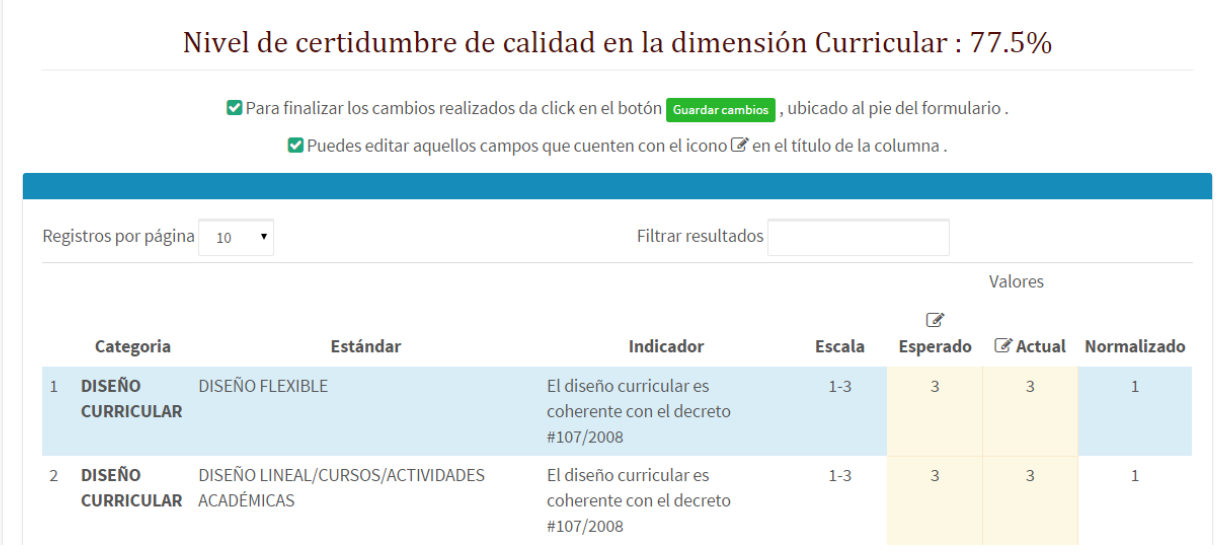

Figure 2. Computer design of the model of postgraduate quality assurance (Careaga \& Meyer, 2013).

\section{Validation of Expert and User Judgment's Results}

Results are structured according to the eight dimensions of the model. In general, statistical data show agreement referring to the acceptance of the dimensions where the mean is 4.5.

Regarding to the institutional dimension, it was accepted by the majority of the judges and users $(M=4.3)$ this means that the model measures the quality that a program should consider in its institutional aspects and it can be inferred that the averages obtained meet the requirements for approval. At the same time the category named consistency with the educational project has the highest level of acceptance $(M=4.8)$ and the category of curricular framework has the lowest level of acceptance $(M=3.8)$ (See Table 1$)$.

Table 1

Institutional Dimension's Results

\begin{tabular}{lllll}
\hline Category & $M$ & $S D$ & Min & Max \\
\hline $\begin{array}{l}\text { Consistency with the educational project } \\
\text { Curricular framework }\end{array}$ & 4.8 & 0.39 & 4 & 5 \\
$\begin{array}{l}\text { Strategic development plan of the } \\
\text { faculty/institute }\end{array}$ & 3.4 & 1.5 & 1 & 5 \\
\hline
\end{tabular}

The curricular dimension was accepted by the judges and users $(M=4.7)$. This means that it contributes to the clarity in the processes of quality assurance for postgraduate programs. Moreover, there is no substantial difference in the results shown in Table 2. The curricular design, the mode, the admission requirements, and the graduate profile show an average of 5.0: that means that they were approved with the highest level of acceptance. Furthermore, the Curriculum type category has 
Quality Assurance for Postgraduate Programs: Design of a Model Applied on a University in Chile

Careaga Butter, Meyer Aguilera, Badilla Quintana, Jiménez Pérez, and Sepúlveda Valenzuela

the lowest level of acceptance $(M=4.0$ ), which is still a positive result and it can be inferred that the averages obtained fulfil the requirements for approval (See Table 2).

Table 2

Curricular Dimension's Results

\begin{tabular}{lllll}
\hline Category & $M$ & $S D$ & Min & Max \\
\hline Curricular design & 5.0 & 0.00 & 5.0 & 5.0 \\
Program types & 4.9 & 0.25 & 4.0 & 5.0 \\
Mode & 5.0 & 0.00 & 5.0 & 5.0 \\
Admission requirements & 5.0 & 0.00 & 5.0 & 5.0 \\
Student selection process & 4.8 & 0.34 & 4.0 & 5.0 \\
Graduate Profile & 5.0 & 0.00 & 5.0 & 5.0 \\
Graduation Requirements & 4.9 & 0.25 & 5.0 & 5.0 \\
Educational processes & 4.5 & 0.78 & 4.0 & 5.0 \\
Flexibility & 4.5 & 1.13 & 1.0 & 5.0 \\
Curriculum type & 4.0 & 1.81 & 1.0 & 5.0 \\
Curricular approach & 4.5 & 1.20 & 1.0 & 5.0 \\
Plans and programs & 4.7 & 0.65 & 3.0 & 5.0 \\
Undergraduate-postgraduate articulation & 4.5 & 0.78 & 5.0 & 5.0 \\
\hline
\end{tabular}

Regarding the academic dimension the results obtained shows an average of $4.4(M=4.4)$. Furthermore, there are important differences in the results shown in Table 3 where two categories, mobility and advanced human capital formation, obtained the lowest level of acceptance (M=3.7). It means that their four indicators needed improvement but they were accepted. It can be deduced that the averages obtained in the rest of categories fulfil the requirements to be endorsed (See Table 3). 
Quality Assurance for Postgraduate Programs: Design of a Model Applied on a University in Chile

Careaga Butter, Meyer Aguilera, Badilla Quintana, Jiménez Pérez, and Sepúlveda Valenzuela

Table 3

Academic Dimension's Results

\begin{tabular}{lcccc}
\hline Category & $M$ & $S D$ & Min & Max \\
\hline Endowment & 4.8 & 0.40 & 4.0 & 5.0 \\
Teaching quality & 4.9 & 0.25 & 4.0 & 5.0 \\
Research capability of teachers & 4.5 & 1.09 & 1.0 & 5.0 \\
Collaboration networks & 3.9 & 1.75 & 1.0 & 5.0 \\
Mobility & 3.7 & 1.69 & 1.0 & 5.0 \\
Retention & 4.8 & 0.54 & 5.0 & 5.0 \\
Graduation & 4.9 & 0.25 & 4.0 & 5.0 \\
Quality monitoring & 4.6 & 0.78 & 2.0 & 5.0 \\
Advanced human capital formation & 3.7 & 1.61 & 1.0 & 5.0 \\
\hline
\end{tabular}

According to the findings obtained from the research dimension, it shows an average of 4.2. Furthermore, there are important differences in the results shown in Table 4 where the category knowledge management $(M=2.6)$ was rejected and its indicators were changed for two new ones. Moreover, the postdoctoral category was considered with the lowest level of acceptance because the university does not have any postdoctoral program. However, it is important to consider it for future programs. On the other hand, the master and medical specialties categories were accepted $(M=5.0)$ at the highest level (See Table 4). 
Quality Assurance for Postgraduate Programs: Design of a Model Applied on a University in Chile

Careaga Butter, Meyer Aguilera, Badilla Quintana, Jiménez Pérez, and Sepúlveda Valenzuela

Table 4

Research Dimension's Results

\begin{tabular}{lcccc}
\hline Category & $M$ & $S D$ & Min & Max \\
\hline Postgraduate integration research & 4.9 & 0.25 & 4.0 & 5.0 \\
Postdoctoral & 3.0 & 1.63 & 1.0 & 5.0 \\
Doctoral & 4.7 & 0.50 & 3.0 & 5.0 \\
Master & 5.0 & 0.00 & 5.0 & 5.0 \\
Medical specialties & 5.0 & 0.00 & 5.0 & 5.0 \\
Knowledge management & 2.6 & 1.74 & 1.0 & 5.0 \\
\hline
\end{tabular}

According to the findings obtained from The Management Dimension, it was accepted by judges and users $(M=4.9)$ contributing to the clarity in the processes of quality assurance for postgraduate programs. Moreover, there are no important differences in the results shown in Table 5 . The selfevaluation, self-regulation, accreditation, rules and regulations, and funding categories show an average of 5.0, meaning that they were approved with the highest level of acceptance. Furthermore, the employability category has the lowest level of acceptance $(M=4.4)$, which is still a positive result and it can be inferred that the averages obtained fulfil the requirements for approval (see Table 5).

Table 5

Management Dimension's Results

\begin{tabular}{lcccc}
\hline Category & $M$ & $S D$ & Min & Max \\
\hline Self-evaluation & 5.0 & 0.00 & 5.0 & 5.0 \\
Self-regulation & 5.0 & 0.00 & 5.0 & 5.0 \\
Accreditation & 5.0 & 0.00 & 5.0 & 5.0 \\
Rules and regulations & 5.0 & 0.75 & 2.0 & 5.0 \\
Funding & 5.0 & 0.00 & 5.0 & 5.0 \\
Administration & 4.9 & 0.25 & 4.0 & 1.0 \\
Employability & 4.4 & 1.00 & 5.0 & 5.0 \\
\hline
\end{tabular}


Quality Assurance for Postgraduate Programs: Design of a Model Applied on a University in Chile

Careaga Butter, Meyer Aguilera, Badilla Quintana, Jiménez Pérez, and Sepúlveda Valenzuela

According to the findings obtained from the infrastructure dimension, it was accepted by judges and users $(M=5.0)$ contributing to the clarity in the processes of quality assurance for postgraduate programs and its categories show an average of 5.0 and 4.9 (see Table 6).

Table 6

Infrastructure Dimension's Results

\begin{tabular}{lcccc}
\hline Category & $M$ & $S D$ & Min & Max \\
\hline For teaching & 5.0 & 0.00 & 5.0 & 5.0 \\
For research & 4.9 & 0.25 & 4.0 & 5.0 \\
\hline
\end{tabular}

Regarding the services dimension, it was accepted by the majority of the judges and users $(M=4.6)$ that this means that the model measures the quality that a program should consider in its services aspects and it can be inferred that the averages obtained meet the requirements for approval. At the same time the categories named library and computer have the highest level of acceptance $(M=5.0)$ and the category of student participation events has the lowest level of acceptance $(M=3.9)$. Below is a table of the averages obtained for each category (see Table 7).

Table 7

Services Dimension's Results

\begin{tabular}{lllll}
\hline Category & M & SD & Min & Max \\
\hline Library & 5.0 & 0.00 & 5.0 & 5.0 \\
Computer & 5.0 & 0.00 & 5.0 & 5.0 \\
Scholarship systems & 4.4 & 1.35 & 1.0 & 5.0 \\
Student participation events & 3.9 & 1.75 & 5.0 & 5.0 \\
\hline
\end{tabular}

Regarding the entailment dimension, it was accepted by the majority of the judges and users $(M=4.5)$ that this means that the model measures the quality that a program should consider in its entailment aspects and it can be inferred that the averages obtained meet the requirements for approval. Furthermore, the category related to with the society has the highest level of acceptance $(M=5.0)$ and the categories related to with the company, with the public system, and institutional have the lowest level of acceptance $(M=4 \cdot 3)$. Below is a table of the averages obtained for each category (see Table 8). 
Quality Assurance for Postgraduate Programs: Design of a Model Applied on a University in Chile

Careaga Butter, Meyer Aguilera, Badilla Quintana, Jiménez Pérez, and Sepúlveda Valenzuela

Table 8

Entailment Dimension's Results

\begin{tabular}{lcccc}
\hline Category & $M$ & $S D$ & Min & Max \\
\hline With the society & 5.0 & 0.00 & 5.0 & 5.0 \\
With the company & 4.3 & 1.34 & 1.0 & 5.0 \\
With the public system & 4.3 & 1.33 & 1.0 & 5.0 \\
Institutional & 4.3 & 1.33 & 1.0 & 5.0 \\
\hline
\end{tabular}

To sum up, the statistical data shows that the dimension and categories' averages obtained met the requirements for approval where the main changes were applied into their indicators.

\section{The Model of Quality Assurance for Postgraduate Programs}

This model is designed from the result of the theoretical, mathematical, and informatics frame. It is a theoretical system, which aims to provide guidance for the process of self-evaluation, self-regulation leading to the design and implementation of improvement plans, and processes of accreditation of graduate programs (see Figure 3).

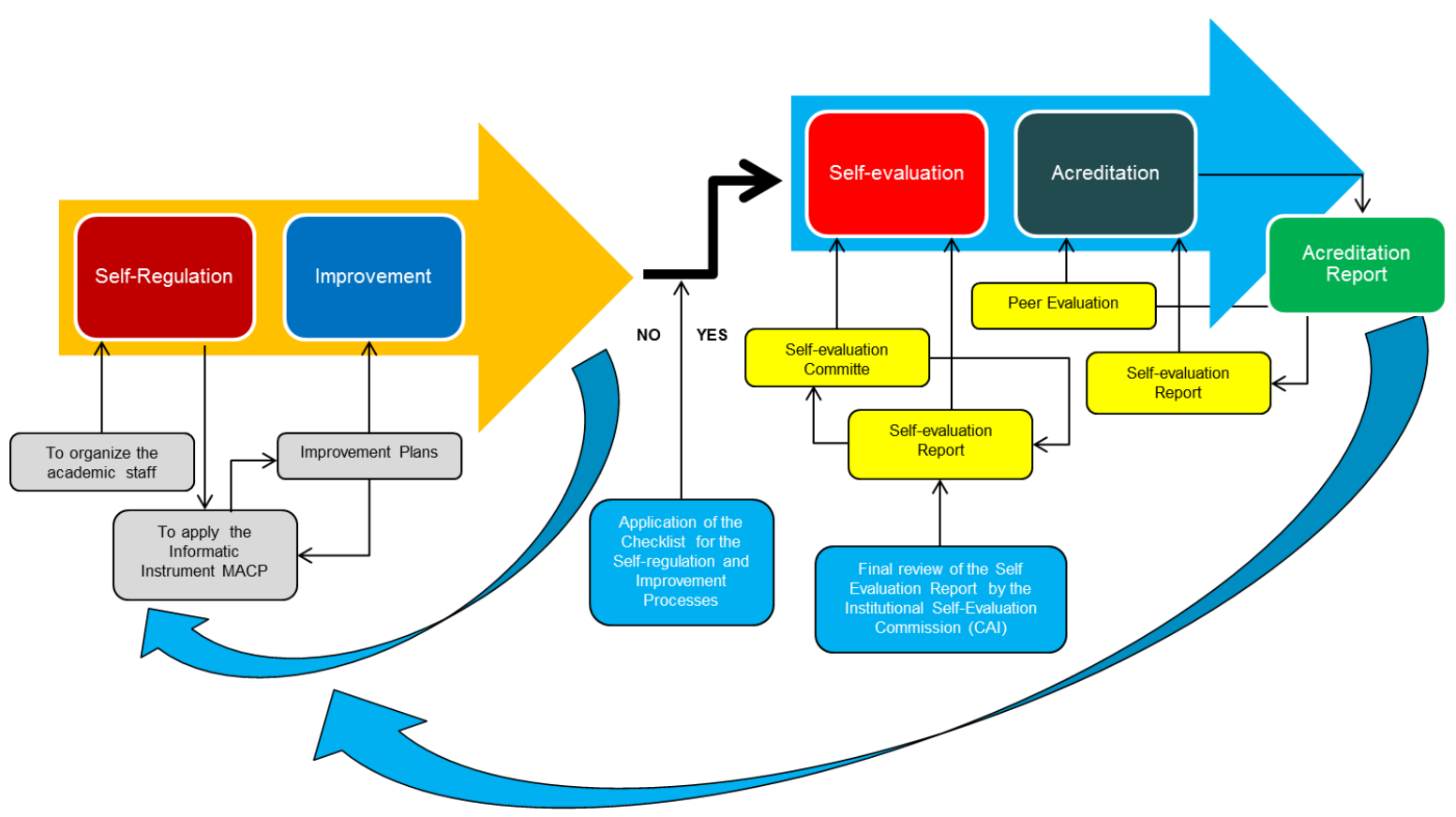


Quality Assurance for Postgraduate Programs: Design of a Model Applied on a University in Chile

Careaga Butter, Meyer Aguilera, Badilla Quintana, Jiménez Pérez, and Sepúlveda Valenzuela

Figure 3. Model of quality assurance for postgraduate programs (own elaboration).

The model consists of four main recursive stages: Self-regulation; Improvement; Self-evaluation and Accreditation.

Self-regulation consists of creating excellent conditions to ensure the quality of the postgraduate programs by developing permanent processes of revision of the institutional, academic, curricula, management dimension consider on each program, in order to improve until obtaining an optimum state according to the quality standards that the model defines. In these stages those responsible for the curricula and administrative and financial management are in charge of the process and the academic staff. They are able to make decisions about the implementation of continuous improvement.

The phases of self-regulation are:

$>$ to organize the academic staff, which is formed by the head of program and the main staff of teachers that give classes and direct theses. The purpose of this committee is to conduct academic development, self-regulation processes, and programs' improvement.

$>$ to apply the informatics instrument MQAPP including all the relevant information of each program.

The improvement stage consists of developing strategies and implementing courses of action in order to consolidate the strengths and overcome the weaknesses of a postgraduate program. The authority in charge must determine goals, timelines, responsibilities, and measurable or observable predefined evidence. The formalization of this process is done through improvement reports.

Its phases are:

$>$ to prepare a report about the main weaknesses of the program and how to improve them. The postgraduate direction delivers the format of this report.

$>$ to create actions to improve and provide a deadline to achieve them.

At the end of the self-regulation and improvement processes, a checklist must be applied to decide to start the next stage. It consists of the 39 most important indicators for the university.

Self-evaluation stage consists of review processes from the institutional, academic, curricular, and management performance of a postgraduate program. An impartial commission of qualified academics analyze and criticize this task to draw a contrast between the program level of development and pre-established quality standards by public agencies and private agencies. 
Quality Assurance for Postgraduate Programs: Design of a Model Applied on a University in Chile

Careaga Butter, Meyer Aguilera, Badilla Quintana, Jiménez Pérez, and Sepúlveda Valenzuela

Its phases are:

$>$ to organize a self-evaluation committee.

$>$ to prepare the self-evaluation report.

$>$ to check the final review of the self-evaluation report by the Institutional Self-Evaluation Commission (CAI).

Accreditation stage consists of certifying the quality levels demonstrated by a postgraduate program. It is accredited by duly authorized public or private organizations, which are responsible for determining whether the self-evaluation process corresponds to the reality of what was developed in the program. Then the agency evaluates the number of years of accreditation according to the established levels or rejects if the program does not have the minimum expected level of quality.

Its phases are: To approve the Peer Evaluation, and to prepare the final Self-evaluation Report and Accreditation Report.

Despite that this model was designed for in-person postgraduate programs, it can be applied to long distance education programs in its several modalities: e-learning, b-learning, and m-learning. Nevertheless it would be necessary to incorporate other specific standards of these modalities, such as (a) technology standards (interface design, connectivity, interactivity, and navigability, among others); (b) pedagogical standards (new roles, virtual tutoring, curriculum distribution or evaluative procedures); and (c) management standards (curriculum management, administrative management, financial management, and technology management).

\section{Conclusions}

The conclusions obtained by this study are consistent with the base of the model. They consider three elements: theoretical, mathematics, and technological. The foundation of a MQAPP requires it to be set on the basis of a solid conceptual definition about quality, to guide the design and implementation of the model. The predominant notion that best fits this model is aligned with overall quality of comprehensively training people to perform competently and effectively in reality understood in its complexity and the necessary integration and knowledge management for better conditions of life and happiness.

The mathematical model combines a set of indicators of disparate values through standardization, giving equal value to all thanks to the choice of the relative weight of each. This value of quality (percentage of compliance with the indicators of the dimension) is valid as the choice of indicators that was obtained through an appropriate methodology: expert information, survey of teachers, focus group, national and international benchmarks, among others. 
Quality Assurance for Postgraduate Programs: Design of a Model Applied on a University in Chile

Careaga Butter, Meyer Aguilera, Badilla Quintana, Jiménez Pérez, and Sepúlveda Valenzuela

The implementation of the mathematical model was flexible enough to add or delete indicators during the prototype stage. Also the equation applied to each dimension is a quality assurance tool that allows the academic unit to improve in that dimension to detect those dimensions with low or zero value. In this last case is a warning that the unit is not fulfilling some of the minimum requirements for accreditation that are requested. In the prototype all weights (e.g., in equation 1) are equal to the unit used. It is expected in the next stages that the design of a new prototype to improve and define the set of weights according to priorities will be established by the university authority.

The design of a software platform based on incremental prototyping model was perceived to be beneficial because it can be applied in real context, subjecting its components to a recursive process of design, pilot, validation, and optimization that allows evaluation and optimization.

Thus, overall, the feedback from experts and users helps to reduce the number of indicators of the model. At the end of the first process, the model has 137 indicators. In order to achieve a successful model, it is important to generate a conceptual brochure for internal use in order to establish and clarify the most important concepts used in the model to unify the different knowledge areas of the university. Moreover, the informatics instrument is going to keep the reusable information up in order to save working time and it is going to be intelligent to take the decision of going or not to the third stage, the self-evaluation.

These findings strongly support the need to have a model that gives guidelines to manage the selfregulation processes to achieve quality. However, the participation of each postgraduate program's coordinators is essential because they can recognize the relevant critical points through the application and preparation of an improvement plan taking in consideration the potential impact that it has in the accreditation of the program.

Some final reflections to consider about the model for postgraduate programs proposed in this paper include the analysis of complementary data, which must be triangulated in order to pass to an accreditation stage. The model has a flexible design which could be adapted both the type of program and the definition of new standards. Currently the model is being strengthened, taking into consideration a comprehensive review the program structure, a curriculum analysis to update the graduate profiles, tracking graduates, and consultation to employers.

Also the model of quality assurance presented could be an interesting contribution, since it can be applied in other postgraduate systems, but requires considering and including local adaptations to the standards defined in each educational institutions or countries.

The quality model might be guided by educating ethical and moral people. They should be able to coconstruct knowledge, to integrate disciplines and understanding the complexity of reality. Moreover, it is helpful to motivate and to educate people who develop a respectful identity and promote a tolerant performance in a society built in interculturality where the notion of education implies cultivating the most authentic expressions of knowledge, science, technology, art, sports, and culture. 
Quality Assurance for Postgraduate Programs: Design of a Model Applied on a University in Chile

Careaga Butter, Meyer Aguilera, Badilla Quintana, Jiménez Pérez, and Sepúlveda Valenzuela

\section{Acknowledgments}

This research is conducted with the support of the Postgraduate Direction and the Unit of Educational Computing and Knowledge Management, from the Faculty of Education of Universidad Católica de la Santísima Concepción.

\section{References}

Rubio, M., Aguilar, R., Massa, P., Maldonado, J., \& Ramírez, Ll. (2005). Memoria. Proyecto: Centro virtual para el desarrollo de estándares de calidad para la educación superior a distancia en América Latina y el Caribe. CALED [Memory. Project: Virtual center for the development of quality standards for higher distance education in Latin America and the Caribbean]. Retrieved from http://www.caledead.org/sites/default/files/files/INTRODUCTORIO.pdf

CALED. (n.d.). Certificación. [The institute's service statement.] Retrieved from http://www.caledead.org/servicios/certificacion

Careaga, M., \& Meyer, E. (2013). Computer design model quality assurance postgraduate. Unpublished document.

Careaga Butter, M., Badilla Quintana, M. G., \& Sepulveda Valenzuela, E. (2014). Incremental prototyping model for the development of educational platforms: A process of design and quality standards. Journal of Universal Computer Science, 2O(10), 1407-1417.

Centro Interuniversitario de Desarrollo (CINDA) - Universia. (2012). Aseguramiento de la calidad en Iberoamérica. Educación superior informe 2012 [Quality assurance in Latin America. Higher education report 2012]. Santiago de Chile: RIL Editores. Retrieved from http://www.cinda.cl/informes-educacion-superior-en-iberoamerica/

Colin O. L. (2002). Las normas ISO 9000:2000 de Sistemas de Gestión de la Calidad [The ISO 9000: 2000 Quality management system standards]. Boletín IIE, Julio-Agosto, 182-188. Retrieved from http://www.iie.org.mx/bolISO02/tecni2.pdf

Consejo de Rectores de las Universidades Chilenas. (N/D). Aporte al país [Contribution to the country]. Retrieved from http://www.consejoderectores.cl/web/consejo aporte.php

Comisión Nacional de Acreditación (CNA). (2013). Aprueba criterios para la acreditación de programas de postgrado [Approves criteria for the accreditation of postgraduate programs]. Resolución Exenta DJ Nºo6-4. Retrieved from https://www.cnachile.cl/Criterios\%20y\%20Procedimientos/RES-DJ-006-41.pdf 
Quality Assurance for Postgraduate Programs: Design of a Model Applied on a University in Chile

Careaga Butter, Meyer Aguilera, Badilla Quintana, Jiménez Pérez, and Sepúlveda Valenzuela

Comision Nacional de Acreditación (CNA) (2015). Orientaciones sobre productividad por comités de área (Actualizado el 18-06-2015) [Productivity guidance by area committees (Updated 6/18/2015)]. Retrieved from

https://www.cnachile.cl/Documentos\%20de\%20Paginas/ORIENTACIONES\%20DE\%20P RODUCTIVIDAD\%20POR\%20COMIT\%C3\%89S\%20DE\%20AREA\%2018-06-2015.pdf

The Council of Regional Accrediting Commissions. (2009). Guidelines for the evaluation of electronically offered degree and certificate programs. Retrieved from http://download.hlcommission.org/C-RAC Distance Ed Guidelines 731 2009.pdf

Distance Education Accrediting Commission (DEAC). (2016). Policies, procedures, standards and guides of the distance education accrediting commission. Distance Education Accrediting Commission. Washington, DC: authors. Retrieved from http://www.deac.org/UploadedDocuments/2016-Handbook/2016-DEAC-AccreditationHandbook.pdf

ENQA. (2009). Standards and guidelines for quality assurance in the European higher education area. Helsinki, Finland: European Association for Quality Assurance in Higher Education. Retrieved from http://www.enqa.eu/wp-content/uploads/2013/06/ESG 3edition-2.pdf

Pitta, E. G. (2013). Estudio del sistema de aseguramiento de la calidad de la educación superior. Un análisis politológico de formulación de política pública [Quality assurance study of the higher education system. A politological analysis of public policy formulation]. Revista Enfoques, 11(19), 139-166.

El-Khawas, E. (2007). Acreditación de la educación terciaria en Estados Unidos y Canadá [Accreditation of tertiary education in the United States and Canada]. In Sanyal, \& Tres (Eds.), La educación superior en el mundo 2007: Acreditación para la garantía de la calidad: ¿Qué está en juego? [Higher education in the world 2007: Accreditation for quality assurance: What is at stake?]. Retrieved from

http://upcommons.upc.edu/handle/2099/7536

García Retana, J. A. (2011). Modelo educativo basado en competencias: importancia y necesidad [Competence-based educational model: importance and necessity]. Revista Electrónica Actualidades Investigativas en Educación, 11(3), 1-24. Retrieved from http://www.redalyc.org/pdf/447/44722178014.pdf

Hristova, M., \& Zhelezarov, I. (2006). Modelling of the criteria for measurement and assessing the quality of university education. Facta Universitatis (NIŠ)-Series: Electronics and Energetics, 19(3), 393-404. Retrieved from http://www.doiserbia.nb.rs/img/doi/03533670/2006/0353-36700603393H.pdf 
Quality Assurance for Postgraduate Programs: Design of a Model Applied on a University in Chile Careaga Butter, Meyer Aguilera, Badilla Quintana, Jiménez Pérez, and Sepúlveda Valenzuela

Hernández Sampieri, R., Fernández Collado, C., \& Baptista Lucio, P. (2010). Metodología de la investigación [Investigation of methodology]. México: McGraw-Hill Interamericana.

The Institute for Higher Education Policy. (2000). Quality on the line: Benchmarks for success in internet-based distance education. Washington, DC: The Institute for Higher Education Policy. Retrieved from http://www.americanbar.org/content/dam/aba/migrated/legaled/distanceeducation/Qual ityOnTheLine.authcheckdam.pdf

Johnson, R. B., Onwuegbuzie, A. J., \& Turner, L. A. (2007). Toward a definition of mixed methods research. Journal of Mixed Methods Research, 1(2), 112-133.

Juran, J. M., \& Godfrey, A.B. (2001). Manual de calidad [Manual of quality]. Madrid: Mc Graw Hill.

Middle States Commission on Higher Education (MSCHE). (2009). Characteristics of excellence in higher education. Retrieved from http://www.msche.org/publications/CHXo6_Augo8REVMarcho9.pdf

OECD. (2013). Organisation for economic co-operation and development, OECD. Retrieved from http://www.oecd.org/

Ossiannilsson, E., Williams, K., Camilleri, A., \& Brown, M. (2015). Quality models in online and open education around the globe: State of the art and recommendations. International Council for Open and Distance Education. Retrieved from http://www.icde.org/assets/WHAT WE DO/icdequalitymodels22.pdf

QAA. (n.d.). The UK quality code for higher education. Retrieved from http://www.qaa.ac.uk/assuring-standards-and-quality/the-quality-code

Rubio, M. J. (2003). Enfoques y modelos de evaluación del e-learning [E-learning approaches and evaluation models]. Relieve, 9(2), 101-120. Retrieved from http://www.uv.es/RELIEVE/vgn2/RELIEVEvgn2 1.htm

Sangrà, A. (2001a). BENVIC project. Benchmarking of virtual campuses. Universitat Oberta de Catalunya. Retrieved from http://www.benvic.odl.org/indexpr.html

Sangrà, A. (2001b). La calidad en las experiencias virtuales de educación superior [Quality in virtual experiences in higher education]. In Actas de la conferencia internacional sobre educación, formación y nuevas tecnologías [Proceedings of the International Conference on Education, Training and New Technologies] (pp. 614-625). Retrieved from http://mc142.uib.es:8080/rid=1JXCH278X-2CNMN7K21Y/ARTICULO\%20CAMPUS\%20VIRTUAL.pdf 
Quality Assurance for Postgraduate Programs: Design of a Model Applied on a University in Chile

Careaga Butter, Meyer Aguilera, Badilla Quintana, Jiménez Pérez, and Sepúlveda Valenzuela

Santillán, J., \& Asmat, F. (2015). Modelo de gestión estratégica para mejorar la calidad de los servicios de salud e ingresos económicos del Hospital Regional Docente de Trujillo [Strategic management model to improve the quality of health services and economic income of the Trujillo Regional Teaching Hospital]. Revista Ciencia y Tecnología, 1o(4), $175-190$

SINAES. (2011). Modelo de acreditación oficial de carreras de grado del sistema nacional de acreditación de la educación superior para la modalidad a distancia [Official accreditation model of degree programs of the national system for accreditation in higher education for elearning]. Costa Rica: SINAES. Retrieved from http://www.sinaes.ac.cr/images/docs/proceso acreditacion/manual distancia 11.pdf

Universidad Católica de la Santísima Concepción (UCSC). (2003). Proyecto educativo institucional D.R.No 61-2003 [Institutional educational project, D.R. No. 61-2003]. Retrieved from http://admision.ucsc.cl/wpcontent/uploads/2011/05/PROYECTO EDUCATIVO VERSION AP.pdf

Universidad Católica de la Santísima Concepción (UCSC). (2010). Marco curricular. Decreto de rectoría 119/2010. [Curricular framework. Decree of rectoría 199/2010] Unpublished document.

Universidad Católica de la Santísima Concepción (UCSC). (2012). Plan de desarrollo estratégico UCSC [UCSC strategic development plan]. Retrieved from http://www.ucsc.cl/wpcontent/uploads/2009/10/Plan-Desarrollo-Estrategico.pdf

United Nations Educational, Scientific and Cultural Organization (UNESCO). (2009). Conferencia mundial sobre educación superior 2009: "Las Nuevas Dinámicas de la Educación Superior y de la Investigación para el Cambio Social y el Desarrollo" [World conference on higher education 2009: "The New Dynamics of Higher Education and Research for Social Change and Development”]. París: Unesco. Retrieved from http://www.unesco.org/education/wche/CMES Folleto informativo 25032009.pdf

Varela-Ruiz, M., Díaz-Bravo, L., \& García-Durán, R. (2012). Descripción y usos del método Delphi en investigaciones del área de la salud [Description and uses of Delphi research method in the area of health]. Investigación en Educación Médica, 1(2), 90-95.

Athabasca University

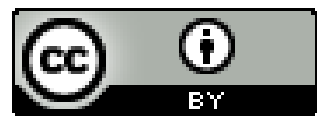

